\title{
Pertussis hospitalizations among term and preterm infants: clinical course and vaccine effectiveness
}

Nicoline A. T. van der Maas ${ }^{1 *}$ (D, Elisabeth A. M. Sanders ${ }^{2}$, Florens G. A. Versteegh ${ }^{3}$, Albertine Baauw ${ }^{4}$, Anneke Westerhof ${ }^{1}$ and Hester E. de Melker ${ }^{1}$

\begin{abstract}
Background: Pertussis causes severe disease in young unvaccinated infants, with preterms potentially at highest risk. We studied pertussis in hospitalized infants as related to gestational age (GA) and vaccination history.

Methods: Medical record data of 0-2y old patients hospitalized for pertussis during 2005-2014 were linked to vaccination data. Multivariable logistic regression was used to study the association between GA and vaccination history on the clinical disease course. We compared vaccine effectiveness (VE) against hospitalization for pertussis between term and preterm infants (i.e., $<37 \mathrm{w}$ GA) using the screening method as developed by Farrington.

Results: Of 1187 records, medical data from 676 were retrieved. Of these, 12\% concerned preterms, whereas they are $8 \%$ of Dutch birth cohorts. Median age at admission was $3 \mathrm{~m}$ for preterms and $2 \mathrm{~m}$ for terms $(p<0.001)$. Preterms more often had received pertussis vaccination (62\% vs 44\%; $p=0.01$ ) and more often had coinfections ( $37 \%$ vs $21 \% ; p=0.01$ ). Preterms tended more often to have complications, to require artificial respiration or to need admittance to the intensive care unit (ICU). Preterms had longer ICU stays ( $15 \mathrm{~d}$ vs $9 \mathrm{~d}$; $p=0.004$ ).

Vaccinated preterms and terms had a lower median length of hospital stay and lower crude risks of apneas and the need for artificial respiration, additional oxygen, and ICU admittance than those not vaccinated. After adjustment for presence of coinfections and age at admittance, these differences were not significant, except the lower need of oxygen treatment in vaccinated terms. Effectiveness of the first vaccination against pertussis hospitalizations was 95\% (95\% Cl 93-96\%) and 73\% (95\% Cl 20-91\%) in terms and preterms, respectively. Effectiveness of the second dose of the primary vaccination series was comparable in both groups (86 and 99\%, respectively).
\end{abstract}

Conclusions: Infants hospitalized for pertussis suffer from severe disease. Preterms were overrepresented, with higher need for intensive treatment and less VE of first vaccination. These findings stress the need for alternative prevention, in particular prenatal vaccination of mothers, to reduce pertussis in both groups.

Keywords: Pertussis, Preterms, Infants, Hospitalization, Vaccine effectiveness, Vaccination

\section{Background}

Pertussis is a highly contagious respiratory tract infection, caused mainly by Bordetella pertussis and less frequently by Bordetella parapertussis [1]. In the pre-vaccination era, infants and children contracted pertussis in their first years of life, with a clinical course characterized by uncontrollable coughing attacks, often accompanied by paroxysms,

\footnotetext{
* Correspondence: Nicoline.van.der.maas@rivm.nl

${ }^{1}$ Centre for Infectious Disease Control, National Institute for Public Health and the Environment, PObox 1, 3720BA, Bilthoven, The Netherlands Full list of author information is available at the end of the article
}

post-tussive vomiting, and inspiratory whooping. Consistently high vaccination coverage has substantially decreased pertussis in the population $[2,3]$, but newborns too young to be vaccinated remain at high risk for severe complications including apnea, cyanosis, pneumonia, encephalopathy or even death [4]. This risk is increasing due to the worldwide pertussis reemergence in the 1990s, even in areas of high vaccination coverage in all age groups, with transmission of disease from household members to newborns. Today, high pertussis incidences in infants are observed, with incidence peaking every two to three years

(c) The Author(s). 2019 Open Access This article is distributed under the terms of the Creative Commons Attribution 4.0 International License (http://creativecommons.org/licenses/by/4.0/), which permits unrestricted use, distribution, and 
[3, 5, 6]. Worldwide in 2014, an estimated 24 million cases and 160,000 deaths from pertussis occurred in children younger than 5 years, with the African region contributing the greatest share [7]. In the Netherlands, each year approximately $150-180$ children $<2 y$ are hospitalized and one infant, in general too young to be vaccinated, dies due to pertussis [8]. For this reason, many countries are discussing prenatal pertussis vaccination of mothers to protect newborns, and a growing number of countries now recommend it [9]. This measure is effective in preventing pertussis in the first months of life and has decreased the pertussis disease burden in young infants $[10,11]$. In the Netherlands, the Health Council advised that 3rd trimester maternal pertussis vaccination be offered. This is overall very effective in prevention of pertussis in early infancy, but preterms may benefit less due to a smaller timewindow for mother-to-child transfer of antibodies before delivery $[12,13]$. However, vaccine effectiveness (VE) is reportedly lower after 2nd trimester pertussis vaccination [14]. Given the introduction of a maternal vaccination strategy against pertussis in The Netherlands, we sought to gain more insight into the current pertussis burden among hospitalized infants, with special attention to preterms.

\section{Methods}

\section{Setting, data collection, and linkage}

During the study period (2005-2014), the Netherlands' National Immunization Programme included a $3+1$ infant vaccination schedule using pentavalent (2005-2011) or hexavalent (2012-2014) combination vaccines containing acellular pertussis, with doses at 2, 3, 4 and 11 months of age [15]. Vaccination coverage of the infant series was 93.5-95.5\% for all included birth cohorts [2].

We sent a letter with information about the study aim and logistics together with an informed consent form to the boards of all hospitals in the Netherlands. To those that supplied written approval, we sent a list of all records selected from the National Registry of Hospital Care. The relevant medical records were located and data extracted by trained medical students, supervised by a medical doctor (NvdM). Besides birth date, sex, and postal code, data were collected on gestational age (GA) and birth weight, clinical symptoms at admission, date of admission and discharge, diagnostics, and details about the medical situation, complications, treatments, and clinical status at discharge.

In the National Registry of Hospital Care and the vaccination registry, which includes all 0-18-year-olds and any changes in residence, pseudonyms were created based on birth date, sex, and postal code. For infants who moved over time, pseudonyms in the vaccination registry reflected their known postal codes to a maximum of six. Using the pseudonyms, medical record data were linked to the national vaccination registry.
To ensure privacy, a Trusted Third Party was used for certain steps in data collection and data linking. Researchers were allowed to use age only in months.

Medical ethical approval was not needed because no one was subjected to imposed rules or acts. According to Dutch law, informed consent of patients was not required because the study served public interest, and asking permission was not feasible $[16,17]$.

\section{Data sources \\ National Registry of hospital care}

Hospital Care data include the main diagnosis, date of birth, four digits of the postal code, sex, and date of admission or outpatient treatment [18]. We located medical records for 0-2-year-olds with a primary diagnosis of whooping cough between 2005 and 2014 based on the International Classification of Diseases (ICD) codes, i.e., ICD-9 0330 or ICD-10 A370 (caused by B. pertussis); ICD-9 0331 or ICD-10 A371 (B. parapertussis); ICD-9 0338 or ICD-10 A378 (other specified organism); or ICD90339 or ICD-10 A379 (other unspecified organism).

\section{Statistical analysis}

Differences in general characteristics and clinical aspects of pertussis between terms and preterms (defined as born before 37w GA) were described and tested using Pearson's Chi Square or Fisher's exact test for dichotomous and categorical variables, and student t-test or Wilcoxon rank test for continuous variables.

Multivariable logistic regression was performed to assess the association between prematurity and the clinical picture of pertussis and to study the association between pertussis vaccination and clinical characteristics stratified by GA. Data for both analyses were adjusted for age at hospitalization and coinfections.

Vaccine effectiveness (VE), stratified for preterms and terms, was computed using the screening method as developed by Farrington [19]. We used monthly cumulative coverage estimates of a timely first dose, stratified by preterms and terms [20]. In the main analysis, we classified children without exact GA but with written information of a term pregnancy and infants without information on GA as terms. In sensitivity analyses, we included only children with known GA.

Analyses were performed using SAS version 9.4. A $p$ value $<0.05$ was considered statistically significant. Furthermore, term infants were set as reference in all analyses.

\section{Results}

\section{General descriptives}

We invited the participation of 87 hospitals. Of these, 4/8 university hospitals, 19/26 top clinical hospitals, and 27/51 local hospitals participated. Overall, data of $57 \%$ of eligible cases $(676 / 1187)$ were available. 
Of the 676 hospitalized pertussis cases, 80 infants (12\%; 95\%CI 10-14\%) were born preterm, 388 (57\%) were born term, and 208 (31\%) lacked information on gestational age (GA) at birth.

Median GA of preterms at birth was 35w (range $26 \mathrm{w}-36 \mathrm{w})$. Thirteen (16\%) preterms were born before $32 \mathrm{w}$ GA, whereas 67 (84\%) were born between $32 \mathrm{w}-36 \mathrm{w}$ GA.

Among terms and preterms, respectively, $81 \%$ and $75 \%$ of medical records could be linked to vaccination data. Pseudonyms of the remaining records were too unspecific for reliable linkage.

\section{Main analyses $(n=676)$ \\ Hospitalization}

Median age at hospitalization was 2 months (Table 1). Terms were hospitalized at younger ages than preterms (median $2.0 \mathrm{~m}$ vs $3.0 \mathrm{~m}$ ). Median duration of hospitalization was 5 and 6 days for terms and preterms, respectively. Overall, $46 \%$ of infants were vaccinated at admission, with statistically significant higher frequencies in preterms $(62 \%)$ than in terms $(44 \% ; p=0.01)$. Among vaccinated infants, the median interval between first vaccination and hospitalization was $35 \mathrm{~d}$ in terms (mean 106d), compared with $37 \mathrm{~d}$ in preterms (mean 105d).

\section{Clinical course and treatment}

On admittance, $93 \%$ of infants were coughing, and $73 \%$ also suffered from coughing attacks (Table 1). Other classical pertussis symptoms such as prolonged inspiratory effort, whooping, vomiting, and apneas were reported in up to $35 \%$ of infants. Reported symptoms at admission did not differ between terms and preterms, except that cyanosis more often occurred in terms $(44 \%$ vs $31 \% ; p=0.03)$.

Complications like bradycardia, respiratory insufficiency and desaturation, feeding problems, weight loss, and pneumonia were reported in $9 \%$ of infants, with a slightly (not-significant) higher frequency in preterms (Table 1). Two term infants, too young to be eligible for vaccination, died due to pertussis.

Before admission, 20\% of infants already had received antibiotics, whereas $81 \%$ received antibiotics during hospitalization (Table 1). Though preterms were slightly more often treated with intravenous antibiotics, the start and duration of antibiotics was comparable between the groups. We also found a comparable need for additional oxygen (37\% vs 34\%) and ICU admittance (13\% vs $10 \%)$, though a trend to more often need artificial respiration was observed in preterms compared to terms ( $14 \%$ vs $7 \% ; p=0.05)$. Duration of ICU stay was longer in preterms than in terms (median 15 vs 9 days; $p=0.004$ ).
At discharge, $77 \%$ of infants still had symptoms, with coughing most prevalent (Table 1). Likewise, 14\% needed re-admittance within 6 weeks after discharge. Both frequencies were somewhat lower in preterms compared to terms.

\section{Diagnostics}

For 91\% of infants, information on diagnostics to confirm pertussis was found in the medical record (Table 1). In $5 \%$ we found evidence of all three diagnostic procedures (i.e., culture, polymerase chain reaction, and serology), with two procedures in $25 \%$ and one procedure in $64 \%$ of infants.

White blood cell (WBC) counts were available for one third of the medical records; the median highest value was17.2 (range 4.3-106.1), with somewhat lower values in preterms (Table 1). Data on C-reactive protein (CRP) were available for $21 \%$ of records, with lower median CRP in terms than preterms ( 4.7 vs $15 ; p=0.007)$.

In $53 \%$ of the infants, diagnostics were performed for pathogens other than $B$. pertussis (Tables 1 and 2). Overall, preterms were more often tested (61\% vs $51 \%$; $p=0.2)$ and diagnosed (37\% vs $21 \% ; p=0.01)$ with coinfections than terms. Respiratory syncytial virus (RSV), influenzavirus, adenovirus, human meta-pneumovirus, para-influenzavirus, rhinovirus, and Mycoplasma pneumoniae were observed in 21 to $57 \%$ of tested cases, with RSV and para-influenzavirus more often observed in preterms (Table 2). In total, tests for 43 pathogens were performed. Respiratory pathogens are recorded in Table 2.

\section{Influence of coinfections and age at hospitalization on the clinical picture}

Using multivariable logistic regression analysis, we studied the association between the clinical course and treatment of pertussis and prematurity. We adjusted for age at hospitalization and presence of coinfections. Results were in line with the trends mentioned in previous results sections (Table 3). With respect to the need for artificial respiration, the risk among preterms was significantly higher than in terms (adjusted Odds Ratio (OR) 2.8 ; 95\% CI 1.3-6.0). With respect to apnea, preterms showed an increased risk after adjustment (OR 1.8; 95\% CI 1.0-3.3).

\section{Influence of vaccination and vaccine effectiveness (VE)}

Being vaccinated was associated with a reduction in the median duration of hospitalization among both terms $(9$ vs 3 days; $p<0.0001$ ) and preterms (13 vs 5 days; $p=$ 0.01). A lower median duration of ICU admission was found among vaccinated preterms ( 8 vs20 days; $p=0.1$ ), but not in terms. Furthermore, the median highest WBC count was lower in vaccinated terms $(p=0.004)$, but not 
Table 1 Clinical course, diagnostic tests, and treatment of pertussis in term and preterm infants. Denominator is the number of infants in the group, which is noted in column headings or the respective cells

\begin{tabular}{|c|c|c|c|c|}
\hline & Total group $(n=676)$ & $\begin{array}{l}\text { Probable and certain } \\
\text { term infants }(n=596)^{\mathrm{a}}\end{array}$ & $\begin{array}{l}\text { Certain term infants } \\
(n=388)^{\mathrm{b}}\end{array}$ & Preterm infants $(n=80)$ \\
\hline \multicolumn{5}{|c|}{ Characteristics of hospitalization, clinical course, and treatment } \\
\hline Boys; $n(\%)^{1}$ & $335(49.6 \%)$ & $295(49.5 \%)$ & $185(47.7 \%)$ & $40(50 \%)$ \\
\hline Age in months at admittance; median (range) & $2.0(0-36)$ & $2.0(0-35)$ & $2.0(0-35)$ & $3.0(0-25)^{c, d}$ \\
\hline Duration of hospitalization in days; median (range) & $5.0(1-51)$ & $5.0(1-51)$ & $5.0(1-51)$ & $6.0(1-49)$ \\
\hline Admission intensive care unit (ICU); $n(\%)$ & $69(10.2 \%)$ & $59(9.9 \%)$ & $50(12.9 \%)$ & $10(12.5 \%)$ \\
\hline Duration ICU stay in days; median (range) & $9(2-34)$ & $9(2-25)$ & $9(2-25)$ & $15(8-34)^{c, d}$ \\
\hline Vaccinated at admission; $n$ (\%) & $250 / 541(46.2 \%)$ & $213 / 481(44.3 \%)$ & 130/319 (40.7\%) & $37 / 60(61.7 \%)^{c, d}$ \\
\hline Coughing attacks; $n(\%)$ & $494(73.1 \%)$ & $438(73.5 \%)$ & $280(72.2 \%)$ & $56(70.0 \%)$ \\
\hline Apnea; $n(\%)$ & $110(16.3 \%)$ & $92(15.4 \%)$ & $71(18.3 \%)$ & $18(22.5 \%)$ \\
\hline Whooping; $n$ (\%) & $24(3.6 \%)$ & $23(3.9 \%)$ & $18(4.6 \%)$ & $1(1.3 \%)$ \\
\hline Vomiting; $n(\%)$ & $238(35.2 \%)$ & $210(35.2 \%)$ & $146(37.6 \%)$ & $28(35.0 \%)$ \\
\hline Prolonged inspiratory effort; $n$ (\%) & $49(7.3 \%)$ & $42(7.1 \%)$ & $33(8.5 \%)$ & $7(8.8 \%)$ \\
\hline Collapse; $n(\%)$ & $8(1.2 \%)$ & $6(1.0 \%)$ & $5(1.3 \%)$ & $2(2.5 \%)$ \\
\hline Cyanosis; n (\%) & $284(42.0 \%)$ & $259(43.5 \%)$ & $176(45.4 \%)$ & $25(31.3 \%)^{\mathrm{c,d}}$ \\
\hline Fever; $n(\%)$ & $60(8.9 \%)$ & $52(8.7 \%)$ & $33(8.5 \%)$ & $8(10.0 \%)$ \\
\hline Feeding problems; $n$ (\%) & $212(31.4 \%)$ & $185(31.0 \%)$ & $133(34.3 \%)$ & 27 (33.8\%) \\
\hline Any complication ${ }^{\mathrm{e}} ; n(\%)$ & $63(9.3 \%)$ & $53(8.9 \%)$ & $39(10.1 \%)$ & $10(12.5 \%)$ \\
\hline Antibiotics before admission ${ }^{\mathrm{f}} ; n(\%)$ & $131 / 657(19.9 \%)$ & $114 / 580(19.7 \%)$ & $66 / 377(17.5 \%)$ & 18/77 (23.4\%) \\
\hline Antibiotics during admission ${ }^{9} ; n(\%)$ & $543 / 674(80.5 \%)$ & $475 / 587(80.9 \%)$ & $313 / 382(81.9 \%)$ & $68 / 78(87.2 \%)$ \\
\hline Intravenous antibiotics during admission; $n(\%)$ & $12 / 403(3.0 \%)$ & $9 / 357(2.5 \%)$ & $6 / 244(2.5 \%)$ & $3 / 46(6.5 \%)$ \\
\hline Antibiotic use in days; median (range) & $6(0-28)$ & $6(0-28)$ & $5(0-28)$ & $5.5(1-18)$ \\
\hline Artificial respiration; $n(\%)$ & $50 / 654(7.7 \%)$ & $39 / 577(6.8 \%)$ & $32 / 375(8.5 \%)$ & $11 / 77(14.3 \%)^{c}$ \\
\hline Additional oxygen; $n(\%)$ & $226 / 661(34.2 \%)$ & 198/585 (33.9\%) & 150/382 (39.3\%) & $28(36.8 \%)$ \\
\hline Symptoms remaining; $n(\%)$ & $518(76.6 \%)$ & $460(77.2 \%)$ & $298(76.8 \%)$ & $58(72.5 \%)$ \\
\hline Re-admittance $<6 \mathrm{w}$ after discharge; $n(\%)$ & $94(14.0 \%)$ & $85(14.3 \%)$ & $56(14.4 \%)$ & $9(11.4 \%)$ \\
\hline \multicolumn{5}{|l|}{ Diagnostics } \\
\hline Pertussis test: culture, PCR and serology; $n(\%)$ & $34(5.0 \%)$ & $31(5.2 \%)$ & $24(6.2 \%)$ & $3(3.8 \%)$ \\
\hline Pertussis test: culture and PCR; $n(\%)$ & $59(8.7 \%)$ & $52(8.7 \%)$ & $40(10.3 \%)$ & 7 (8.8\%) \\
\hline Pertussis test: PCR and serology; $n$ (\%) & $84(12.4 \%)$ & $73(12.2 \%)$ & $41(10.6 \%)$ & $11(13.8 \%)$ \\
\hline Pertussis test: culture and serology; $n(\%)$ & $24(3.6 \%)$ & $24(4.0 \%)$ & $17(4.4 \%)$ & $0(0 \%)$ \\
\hline Pertussis test: culture; $n(\%)$ & $37(5.5 \%)$ & $29(4.9 \%)$ & $18(4.6 \%)$ & $8(10 \%)$ \\
\hline Pertussis test: PCR; $n(\%)$ & $329(48.7 \%)$ & $290(48.7 \%)$ & $194(50 \%)$ & 39 (48.8\%) \\
\hline Pertussis test: serology; $n$ (\%) & 69 (10.2\%) & $61(10.2 \%)$ & $36(9.3 \%)$ & $8(10 \%)$ \\
\hline Unknown diagnostic test for pertussis; $n$ (\%) & $40(5.9 \%)$ & $36(6.0 \%)$ & $18(4.6 \%)$ & $4(5 \%)$ \\
\hline Result white blood cell counting; $n$ (\%) & $225 / 476(47.3 \%)$ & 200/421 (47\%) & $141 / 276(51.1 \%)$ & $25 / 55(45 \%)$ \\
\hline White blood cell count; median (range) & $17.2(4.3-106.1)$ & $17.7(5.3-106.1)$ & $17.2(5.3-74.3)$ & $13.5(4.3-64.0)$ \\
\hline Result C-reactive protein; $n$ (\%) & $142 / 392(36.2 \%)$ & $119 / 344(35 \%)$ & $81 / 231(35.1 \%)$ & 23/48 (48\%) \\
\hline C-reactive protein; median (range) & $5(0-415)$ & $4.7(0-415)$ & $5(0-415)$ & $15(0-363)^{c, d}$ \\
\hline Positive co-infections ${ }^{\mathrm{h}} ; n$ (\%) & $81 / 355(22.8 \%)$ & $63 / 306(20.6 \%)$ & $46 / 208(22.1 \%)$ & $18 / 49(36.7 \%)^{c, d}$ \\
\hline \multicolumn{5}{|l|}{ Specification of prescribed antibiotics before admission } \\
\hline Amoxicillin & 49/132 (37\%) & $38 / 114(33 \%)$ & $23 / 66(35 \%)$ & $11 / 18(65 \%)$ \\
\hline Azithromycin & 24/132 (18\%) & $21 / 114(18 \%)$ & $17 / 66(26 \%)$ & $3 / 18(18 \%)$ \\
\hline Ceftriaxone & $1 / 132(1 \%)$ & $1 / 114(1 \%)$ & $1 / 66(2 \%)$ & $0 / 0$ \\
\hline
\end{tabular}


Table 1 Clinical course, diagnostic tests, and treatment of pertussis in term and preterm infants. Denominator is the number of infants in the group, which is noted in column headings or the respective cells (Continued)

\begin{tabular}{|c|c|c|c|c|}
\hline & Total group $(n=676)$ & $\begin{array}{l}\text { Probable and certain } \\
\text { term infants }(n=596)^{\mathrm{a}}\end{array}$ & $\begin{array}{l}\text { Certain term infants } \\
(n=388)^{\mathrm{b}}\end{array}$ & Preterm infants $(n=80)$ \\
\hline Clarithromycin & $41 / 132(31 \%)$ & $38 / 114(33 \%)$ & $17 / 66(26 \%)$ & $3 / 18(18 \%)$ \\
\hline Erythromycin & $7 / 132(5 \%)$ & $6 / 114(5 \%)$ & $2 / 66(3 \%)$ & $1 / 18(6 \%)$ \\
\hline Feneticillin & $1 / 132(1 \%)$ & $1 / 114(1 \%)$ & $1 / 66(2 \%)$ & $0 / 0$ \\
\hline Trimethoprim & $1 / 132(1 \%)$ & $1 / 114(1 \%)$ & $1 / 66(2 \%)$ & $0 / 0$ \\
\hline unknown & $7 / 132(5 \%)$ & $8 / 114(7 \%)$ & $4 / 66(6 \%)$ & $0 / 18(0 \%)$ \\
\hline \multicolumn{5}{|c|}{ Specification of prescribed antibiotics during admission } \\
\hline Amoxicillin & $11 / 543(2 \%)$ & 10/475 (2\%) & $7 / 313(2 \%)$ & $1 / 68(1 \%)$ \\
\hline Azithromycin & $170 / 543(31 \%)$ & $146 / 475(31 \%)$ & $98 / 313(31 \%)$ & $24 / 68(35 \%)$ \\
\hline Cephotaxim & $1 / 543(0.2 \%)$ & $0 / 0$ & $0 / 0$ & 1/68 (1\%) \\
\hline Clarithromycin & $314 / 543(58 \%)$ & 280/475 (59\%) & 184/313 (59\%) & $34 / 68(50 \%)$ \\
\hline Erythromycin & $44 / 543(8 \%)$ & $37 / 475(8 \%)$ & $23 / 313(7 \%)$ & $7 / 68(10 \%)$ \\
\hline unknown & $3 / 543(0.6 \%)$ & $2 / 475(0.4 \%)$ & $1 / 313(0.3 \%)$ & $1 / 68(1 \%)$ \\
\hline \multicolumn{5}{|l|}{ Specification of reported complications } \\
\hline conjunctivitis & $5(0.7 \%)$ & $5(0.8 \%)$ & $1(0.3 \%)$ & $0(0 \%)$ \\
\hline convulsion & $5(0.7 \%)$ & $5(0.8 \%)$ & $4(1.0 \%)$ & $0(0 \%)$ \\
\hline encephalopathy & $1(0.2 \%)$ & $1(0.2 \%)$ & $1(0.3 \%)$ & $0(0 \%)$ \\
\hline pneumonia & $11(1.6 \%)$ & $9(1.5 \%)$ & $7(1.8 \%)$ & $2(2.5 \%)$ \\
\hline otitis media & $1(0.2 \%)$ & $1(0.2 \%)$ & $0(0 \%)$ & $0(0 \%)$ \\
\hline death & $2(0.3 \%)$ & $2(0.3 \%)$ & $2(0.5 \%)$ & $0(0 \%)$ \\
\hline bradycardia & $8(1.2 \%)$ & $7(1.2 \%)$ & $6(1.6 \%)$ & $1(1.3 \%)$ \\
\hline cardio-respiratory insufficiency & $7(1.0 \%)$ & $5(0.8 \%)$ & $4(1.0 \%)$ & $2(2.5 \%)$ \\
\hline desaturation & $20(3.0 \%)$ & $18(3.0 \%)$ & $14(3.6 \%)$ & $2(2.5 \%)$ \\
\hline feeding problems & $5(0.7 \%)$ & $2(0.3 \%)$ & $0(0 \%)$ & $3(3.8 \%)$ \\
\hline weight loss & $12(1.8 \%)$ & $11(1.9 \%)$ & $8(2.1 \%)$ & $1(1.3 \%)$ \\
\hline dehydration & $1(0.2 \%)$ & $1(0.2 \%)$ & $1(0.3 \%)$ & $0(0 \%)$ \\
\hline need for drip-feed & $4(0.6 \%)$ & $2(0.3 \%)$ & $1(0.3 \%)$ & $2(2.5 \%)$ \\
\hline gastroenteritis & $3(0.4 \%)$ & $2(0.3 \%)$ & $2(0.5 \%)$ & $1(1.3 \%)$ \\
\hline sepsis & $1(0.2 \%)$ & $1(0.2 \%)$ & $0(0 \%)$ & $0(0 \%)$ \\
\hline extreme high white blood cell count & $2(0.3 \%)$ & $1(0.2 \%)$ & $0(0 \%)$ & $1(1.3 \%)$ \\
\hline metabolic alkalosis & $1(0.2 \%)$ & $1(0.2 \%)$ & $0(0 \%)$ & $0(0 \%)$ \\
\hline hypotonia & $2(0.3 \%)$ & $1(0.2 \%)$ & $1(0.3 \%)$ & $1(1.3 \%)$ \\
\hline
\end{tabular}

term infants in main analysis

$b_{\text {term infants in sensitivity analysis }}$

csignificant difference $(\mathrm{p}<0.05)$ between certain+probable terms and preterms (main analysis)

${ }^{d}$ significant difference $(p<0.05)$ between certain terms and preterms (sensitivity analysis)

especific complications are listed at the end of the table

${ }^{\text {f }}$ Specification of prescribed antibiotics before admission are listed at the end of the table

${ }^{9}$ Specification of prescribed antibiotics during admission are listed at the end of the table

${ }^{\mathrm{h}}$ Specification of diagnostics for coinfections are listed in Table 2

in vaccinated preterms. In both groups, vaccination was significantly associated with a lower crude risk of apneas and the need for artificial respiration, additional oxygen, or ICU admittance (Table 4). In term infants, vaccination appeared to reduce the crude risk of complications and prescription of antibiotics during admission, but the crude risk of antibiotic prescription before admission appeared higher among vaccinated terms. After adjustment for coinfections and age at admittance, differences were no longer significant except for the lower need of oxygen treatment in vaccinated terms.

Among preterms, VE of the first infant dose (i.e., at 2 months of age) was $73 \%$ (95\%CI 20-91\%) compared to 95\% (95\% CI 93-96\%) among terms (Table 5). Effectiveness 
Table 2 Percentages (numbers tested and positive) of pathogens besides B.pertussis causing respiratory symptoms in term and preterm infants. Denominators are specified per cell

\begin{tabular}{|c|c|c|c|c|}
\hline & Total group $(n=676)$ & $\begin{array}{l}\text { Probable and certain term } \\
\text { infants }(n=596)^{\mathrm{a}}\end{array}$ & Certain term infants $(n=388)^{b}$ & Preterm infants $(n=80)$ \\
\hline Respiratory syncytial virus & $21 \%(62 / 293)$ & $19 \%(49 / 257)$ & $20 \%(34 / 169)$ & $36 \%(13 / 36)^{c, d}$ \\
\hline Influenzavirus & $34 \%(38 / 112)$ & $31 \%(29 / 93)$ & $35 \%(22 / 62)$ & $47 \%(9 / 19)$ \\
\hline Adenovirus & $36 \%(35 / 98)$ & $33 \%(27 / 82)$ & $35 \%(18 / 51)$ & $50 \%(8 / 16)$ \\
\hline Human metapneumovirus & $35 \%(28 / 81)$ & $32 \%(22 / 68)$ & $32 \%(12 / 37)$ & $46 \%(6 / 13)$ \\
\hline parainfluenzavirus & $33 \%(25 / 76))$ & $28 \%(18 / 65)$ & $28 \%(12 / 43)$ & $64 \%(7 / 11)^{\mathrm{c}, \mathrm{d}}$ \\
\hline Rhinovirus & $57 \%(40 / 70)$ & $56 \%(33 / 59)$ & $63 \%(25 / 40)$ & $64 \%(7 / 11)$ \\
\hline Mycoplasma pneumoniae & $29 \%(19 / 65)$ & $27 \%(15 / 55)$ & $30 \%(10 / 33)$ & $40 \%(4 / 10)$ \\
\hline Bocavirus & $56 \%(9 / 16)$ & $42 \%(5 / 12)$ & $44 \%(4 / 9)$ & $100 \%(4 / 4)$ \\
\hline Chlamydophila pneumoniae & $41 \%(12 / 29)$ & $48 \%(12 / 25)$ & $60 \%(9 / 15)$ & $0 \%(0 / 4)$ \\
\hline Chlamydia psittaci & $0 \%(0 / 1)$ & $0 \%(0 / 1)$ & not tested & not tested \\
\hline Cytomegalovirus & $33 \%(4 / 12)$ & $22 \%(2 / 9)$ & $33 \%(2 / 6)$ & $67 \%(2 / 3)$ \\
\hline Coronavirus & $56 \%(18 / 32)$ & $50 \%(14 / 28)$ & $56 \%(9 / 16)$ & $100 \%(4 / 4)$ \\
\hline Coxiella burnetii & $0 \%(0 / 7)$ & $0 \%(0 / 6)$ & $0 \%(0 / 4)$ & $0 \%(0 / 1)$ \\
\hline Enterovirus & $39 \%(9 / 23)$ & $42 \%(8 / 19)$ & $40 \%(6 / 15)$ & $25 \%(1 / 4)$ \\
\hline Haemophilus influenzae & $75 \%(3 / 4)$ & $75 \%(3 / 4)$ & $100 \%(3 / 3)$ & not tested \\
\hline Klebsiella oxytoca & $100 \%(1 / 1)$ & not tested & not tested & $100 \%(1 / 1)$ \\
\hline Klebsiella pneumoniae & $100 \%(2 / 2)$ & $100 \%(1 / 1)$ & $100 \%(1 / 1)$ & $100 \%(1 / 1)$ \\
\hline Legionella & $43 \%(3 / 7)$ & $50 \%(3 / 6)$ & $60 \%(3 / 5)$ & $0 \%(0 / 1)$ \\
\hline Moraxella catarrhalis & $100 \%(5 / 5)$ & $100 \%(4 / 4)$ & $100 \%(3 / 3)$ & $100 \%(1 / 1)$ \\
\hline Bordetella parapertussis & $0 \%(0 / 5)$ & $0 \%(0 / 3)$ & $0 \%(0 / 3)$ & $0 \%(0 / 2)$ \\
\hline Parechovirus & $0 \%(0 / 3)$ & $0 \%(0 / 2)$ & $0 \%(0 / 2)$ & $0 \%(0 / 1)$ \\
\hline Streptococcus pneumoniae & $100 \%(3 / 3 \%)$ & $100 \%(1 / 1)$ & $100 \%(1 / 1)$ & $100 \%(2 / 2)$ \\
\hline
\end{tabular}

term infants in main analysis

${ }^{b}$ term infants in the sensitivity analysis

csignificant difference between certain+probable terms and preterms (main analysis)

${ }^{d}$ significant difference between certain terms and preterms (sensitivity analysis)

of the second dose of the primary vaccination series was comparable in both groups at 86 and $99 \%$, respectively.

\section{Sensitivity analyses; $\mathrm{n}=\mathbf{4 6 8}$}

Taking into account only those infants with known GA, findings were comparable to the main analyses, i.e., analyses in relation to prematurity $(n=468)$, vaccination status $(n=379)$, and VE estimates (not all data shown) (Tables 1, 2 and 5).

\section{Discussion}

This medical record study on infant pertussis hospitalizations showed an overrepresentation of preterms, who accounted for $12 \%$ of all pertussis hospitalizations while comprising, on average, $8 \%$ of Dutch birth cohorts [21]. Furthermore, preterms were older than terms at hospitalization and had more often received their first pertussis vaccinations. Effectiveness of this first dose was significantly lower for preterms than for terms. Moreover, preterms tended to need more often intensive treatment and had a longer ICU stay. Likewise, preterms tended to be diagnosed more often with coinfections. Despite lower VE, the first vaccination against pertussis reduced disease severity and the need for intensive treatment in both groups. Coinfections and age at admission influenced the need for intensive treatment and mitigated the beneficial effect of pertussis vaccination.

The overrepresentation of preterms has been reported in other studies. In Norway, 10\% of infant pertussis hospitalizations concerned preterms, compared to $5 \%$ born prematurely nationwide [22]. Similar data are derived from England [13], Australia [23], and Canada [24]. Low birth weight $(\mathrm{LBW})$, which is associated with preterm delivery, was increased among hospitalized pertussis cases in Jerusalem [25]. Likewise, Langkamp et al. showed that LBW infants were at increased risk of pertussis hospitalizations compared to those of normal birth weight [26]. Winter et al. reported that LBW and low GA were associated with increased risk of fatal pertussis [4]. 
Table 3 Multivariable logistic regression analyses of the association between premature delivery and clinical course and treatment of pertussis; crude and adjusted OR and 95\% confidence intervals (95\% Cl)

\begin{tabular}{|c|c|c|c|c|}
\hline & $\begin{array}{l}\text { Probable and certain } \\
\text { term infants }(n=596)^{a, b}\end{array}$ & Preterm infants $(n=80)^{b}$ & Crude OR (95\% Cl) & Adjusted OR $(95 \% \mathrm{Cl})^{\mathrm{C}}$ \\
\hline \multicolumn{5}{|l|}{ Symptoms at admission } \\
\hline Coughing attacks & $438(73.5 \%)$ & $56(70.0 \%)$ & $0.8(0.5-1.4)$ & $0.8(0.5-1.4)$ \\
\hline Apnea & $92(15.4 \%)$ & $18(22.5 \%)$ & $1.6(0.9-2.8)$ & $1.8(1.0-3.3)$ \\
\hline Whooping & $23(3.9 \%)$ & $1(1.3 \%)$ & $0.3(0.04-2.4)$ & $0.3(0.04-2.3)$ \\
\hline Vomiting & $210(35.2 \%)$ & $28(35.0 \%)$ & $1.0(0.6-1.6)$ & $1.0(0.6-1.6)$ \\
\hline Prolonged inspiratory effort & $42(7.1 \%)$ & 7 (8.8\%) & $1.3(0.5-2.9)$ & $1.2(0.5-2.7)$ \\
\hline Collapse & $6(1.0 \%)$ & $2(2.5 \%)$ & $2.5(0.5-12.7)$ & $3.8(0.7-19.7)$ \\
\hline Cyanosis & $259(43.5 \%)$ & $25(31.3 \%)$ & $0.6(0.4-1.0)$ & $0.7(0.4-1.1)$ \\
\hline Fever & $52(8.7 \%)$ & $8(10.0 \%)$ & $1.2(0.5-2.6)$ & $0.9(0.4-2.0)$ \\
\hline Feeding problems & $185(31.0 \%)$ & $27(33.8 \%)$ & $1.1(0.7-1.9)$ & $1.1(0.7-1.9)$ \\
\hline \multicolumn{5}{|l|}{ Complications } \\
\hline Any complication & $53(8.9 \%)$ & $10(12.5 \%)$ & $1.5(0.7-3.0)$ & $1.6(0.8-3.4)$ \\
\hline \multicolumn{5}{|l|}{ Treatment } \\
\hline Antibiotics before admission & $114 / 580(19.7 \%)$ & 18/77 (23.4\%) & $1.1(0.6-2.0)$ & $1.1(0.6-1.9)$ \\
\hline Antibiotics during admission & $475 / 587(80.9 \%)$ & 68/78 (87.2\%) & $1.5(0.7-3.2)$ & $1.8(0.9-3.9)$ \\
\hline Artificial respiration & $39 / 577(6.8 \%)$ & 11/77 (14.3\%) & $2.3(1.1-4.8)$ & $2.8(1.3-6.0)$ \\
\hline Additional oxygen & 198/585 (33.9\%) & $28(36.8 \%)$ & $1.1(0.7-1.9)$ & $1.3(0.8-2.2)$ \\
\hline Admission intensive care unit (ICU) & $59(9.9 \%)$ & $10(12.5 \%)$ & $1.3(0.6-2.7)$ & $1.6(0.8-3.6)$ \\
\hline \multicolumn{5}{|l|}{ Discharge } \\
\hline Symptoms remaining & $460(77.2 \%)$ & $58(72.5 \%)$ & $0.8(0.5-1.3)$ & $0.8(0.5-1.4)$ \\
\hline
\end{tabular}

Term infants are set as reference. Significant results are in bold

aterm infants in main analysis

${ }^{b}$ If denominator is different, it is reported in the cell

cadjusted for coinfections and age in months at admission

The clinical picture in our observational study resembles findings in other retrospective studies. Marshall et al. showed that preterms had a higher pertussis disease severity score (defined by a longer hospital stay, ICU admittance, need for rehydration, respiratory support, coinfections, and the presence of complications) than terms [23]. In England, a longer duration of hospitalization and higher frequencies of ICU admittance and coinfections were observed among preterms, although their frequency of coinfections was lower than we found (10\% vs 37\%) [13].Langkamp et al. reported a higher median age at hospitalization and a longer median length of stay among LBW infants than among those of normal birth weight [26].

Compared to our study, more active and prospective study designs have revealed higher frequencies of clinical characteristics in infants hospitalized for pertussis (both term and preterm) like cyanosis/desaturation (72\%) and apnea (33\%) at admittance [25]. Australian researchers observed higher rates of ICU admittance (18\%) and treatment with antibiotics (96\%) but lower median length of ICU stay (6 days) [27]. In Switzerland, hospitalized infants $<6 \mathrm{~m}$ of age had higher frequencies of coughing attacks $(93 \%)$, whooping $(69 \%)$, vomiting $(59 \%)$ and complications $(24 \%)[28,29]$. As active designs usually profit from more structured clinical observations and documentation in the medical record, the frequencies found in retrospective studies probably underestimate the pertussis burden in terms and preterms [30].

The aim of vaccination against pertussis is to prevent severe disease. Our study confirms that vaccination reduced disease severity and duration of hospitalization, in line with findings in other countries [27, 31-33] and findings in the Netherlands in 2006-2008 [6]. However, VE was found to be higher in our study than, for example, studies in Germany (VE 68\%; 95\%CI 46-81) and New Zealand (VE 43\%; 95\%CI 21-58) report [34, 35]. Unfortunately, no data on GA were provided in those studies. In Scandinavia, the VE of the first pertussis vaccination against hospitalization did not differ between terms and preterms, being $61 \%$ vs $71 \%$ in Norway and $51 \%$ vs $45 \%$ in Denmark [22, 36]. Both countries start their immunization schedule at age 3 months as compared to the Netherlands, where it occurs between 6 weeks to 2 months.

In 2-month-olds, protective maternal antibodies may be higher than in 3-month-olds, and higher in terms than in preterms [37]. Likewise, studies have shown a 


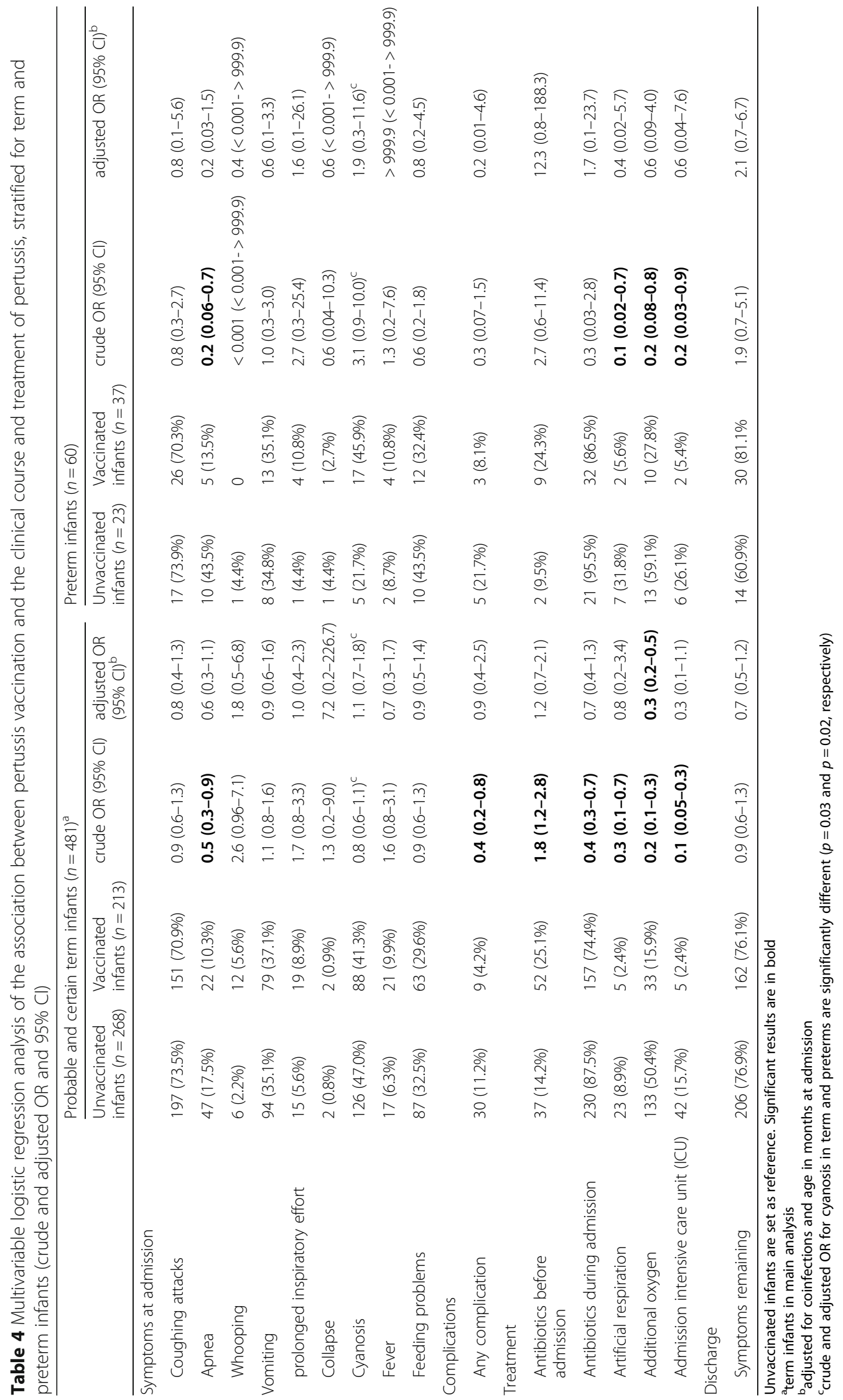


Table 5 Number of infants vaccinated at admission, monthly cumulative coverage estimates, and VE against pertussis hospitalizations of 1st and 2nd infant dose for preterm and term infants, assessed with the screening method

\begin{tabular}{|c|c|c|c|c|c|c|}
\hline \multirow[b]{2}{*}{$\begin{array}{l}\text { Age in } \\
\text { months } \downarrow\end{array}$} & \multicolumn{3}{|l|}{ Term infants } & \multicolumn{3}{|l|}{ Preterm infants } \\
\hline & $\begin{array}{l}\text { Vaccinated at } \\
\text { admission \% (n) }\end{array}$ & $\begin{array}{l}\text { Coverage in general } \\
\text { population }\end{array}$ & $\begin{array}{l}\text { Vaccine effectiveness } \\
(95 \% \mathrm{Cl})^{\mathrm{a}}\end{array}$ & $\begin{array}{l}\text { Vaccinated at } \\
\text { admission \% (n) }\end{array}$ & $\begin{array}{l}\text { Coverage in general } \\
\text { population }\end{array}$ & $\begin{array}{l}\text { Vaccine effectiveness } \\
(95 \% \mathrm{Cl})^{\mathrm{a}}\end{array}$ \\
\hline \multicolumn{7}{|c|}{ Main analysis } \\
\hline $0 \mathrm{~m}$ & $0 \%(0 / 1)$ & na & na & $0 \%(0 / 1)$ & na & na \\
\hline $1 \mathrm{~m}$ & $1.4 \%(2 / 144)$ & $1.9 \%$ & na & $0 \%(0 / 14)$ & $1.3 \%$ & na \\
\hline $2 m$ & $34.2 \%(52 / 152)$ & $90.9 \%$ & $95 \%^{\mathrm{b}}(93-96 \%)$ & $60 \%(9 / 15)$ & $84.9 \%$ & $\begin{array}{l}73 \%^{\mathrm{b}} \\
(20-91 \%)\end{array}$ \\
\hline $3 \mathrm{~m}$ & $85.9 \%(67 / 78)$ & $98.8 \%$ & $93 \%(85-96 \%)$ & $86.7 \%(13 / 15)$ & $97.9 \%$ & $\begin{array}{l}86 \% \\
(9-96 \%)\end{array}$ \\
\hline $4 m$ & $93.8 \%(30 / 32)$ & $99.4 \%$ & $91 \%$ & $100 \%(4 / 4)$ & $99.4 \%$ & na \\
\hline \multicolumn{7}{|c|}{ Sensitivity analysis } \\
\hline $0 \mathrm{~m}$ & $0 \%(0 / 1)$ & na & na & $0 \%(0 / 1)$ & na & na \\
\hline $1 \mathrm{~m}$ & $0.9 \%(1 / 115)$ & $1.9 \%$ & na & $0 \%(0 / 14)$ & $1.3 \%$ & na \\
\hline $2 m$ & $33.7 \%(33 / 98)$ & $90.9 \%$ & $95 \%$ b $(92-97 \%)$ & $60 \%(9 / 15)$ & $84.9 \%$ & $73 \%^{\mathrm{b}}(20-91 \%)$ \\
\hline $3 \mathrm{~m}$ & $89.4 \%(42 / 47)$ & $98.8 \%$ & $90 \%(71-96 \%)$ & $86.7 \%(13 / 15)$ & $97.9 \%$ & 86\% (9-96\%) \\
\hline $4 m$ & $100 \%(14 / 14)$ & $99.4 \%$ & na & $100 \%(4 / 4)$ & $99.4 \%$ & na \\
\hline
\end{tabular}

according to the screening method

${ }^{\mathrm{b}}$ significant difference between term and preterm infants

decreased immune response after immunization at 2 months in preterms compared with terms $[38,39]$ while finding an equal response at 3 months [40]. The fact that the Scandinavian countries saw no difference in VE between term and preterms might be explained by the interplay between maternal antibodies that reduce a first response and an immune response that is ineffective in preterms at age 2 months but may have improved by age 3 months [41]. For the 2nd dose, we found no VE difference between terms and preterms.

As in other studies, we found that the effect of vaccination on the clinical course was influenced by coinfections [13, 23], which included viral infections like RSV [42-47]. However, a recent systematic review concluded that the influence of coinfections on pertussis disease severity remains unclear [48].

Our study has several strengths. It used nationwide data collected over a 10 -year period. The data contained detailed information on clinical characteristics of pertussis, also including information on possible confounding factors, e.g., coinfections. Furthermore, linkage to the vaccination registry enabled us to use validated vaccination records. Finally, the vast majority of the included pertussis cases were laboratory confirmed.

Limitations of our study include the retrospective design and the institutional differences in pertussis diagnostics, diagnostics for coinfections, and registration of clinical and laboratory disease characteristics. The 50\% participation rate of hospitals might have influenced our results, but participating hospitals were spread over the country and showed a good representation of tertiary, top clinical, and local hospitals in the Netherlands. Results might have been influenced by the incomplete reporting of hospital diagnoses at discharge, assessed in a recent capture-recapture analysis [8]. We could not stratify this underreporting by GA, but the good representation of tertiary, top clinical, and local hospitals in our study probably led to inclusion of a representative variety in the spectrum of pertussis disease. This conclusion is underlined by our finding that preterms are overrepresented, as found by other studies.

Further limitations include the retrospective use of medical records, which led to missing data, e.g., on GA, birth weight, with possible impact on our results. For this reason our main analysis was based on all records, assuming that infants with unknown GA were born term. Our sensitivity analysis showed no major impact of missing data on GA, thereby confirming our findings. A breakdown of preterms into smaller groups based on GA would be clinically relevant, but low numbers prohibited this analysis. Likewise, WBCs and CRP data were incomplete, also leading to less informative results.

Linkage between medical records and vaccination data, based on pseudonymization, might have led to error. Medical records include the home address at the patient's last visit, whereas the vaccination registry includes the current home address. Especially in cases of frequent moving and/ or a large interval since the last visit, linkage might be incorrect. In our study, $38 \%$ of infants did not move house. Furthermore, the use of additional pseudonyms based on previous home addresses (also stored in the vaccination registry) lowered the risk of incorrect linking. 


\section{Conclusion}

Preterms were overrepresented among pertussis hospitalizations and had a slightly higher overall risk of complications, increased need for intensive treatment, and lower effectiveness of the first infant pertussis vaccination. The Dutch Health Council recommended maternal pertussis vaccination in the 3rd trimester of pregnancy. While this strategy is overall very effective, preterms may benefit less due to less protective maternal antibody transfer before delivery $[12,13]$. They probably will benefit more from 2nd trimester immunization. Especially for infants born of unvaccinated mothers, a timely first post-natal dose remains important, as it greatly reduces cases of pertussis and decreases disease severity. Our study underlines the need for more in-depth surveillance of vaccine-preventable diseases in relation to GA and more insight into optimizing the vaccination program for all children but in particular for preterms, the most vulnerable group.

\section{Abbreviations}

CRP: C-reactive protein; GA: Gestational age; ICD: International Classification of Diseases; ICU: Intensive care unit; LBW: Low birth weight; OR: Odds Ratio; RSV: Respiratory syncytial virus; VE: Vaccine effectiveness; WBC: White blood cell

\section{Acknowledgements}

We thank J. Alblas for help in data management, P. Oomen for supplying vaccination data, and all participating hospitals for their cooperation.

\section{Authors' contributions}

NvdM, FV and HdM designed the study. NvdM, ES and AW coordinated and supervised data collection. NvdM, AW, FV, AB and medical students collected data. NvdM, HdM, ES and FV interpreted study results. NvdM drafted the initial manuscript. All authors revised subsequent versions, approved the final manuscript as submitted and agree to be accountable for all aspects of the work.

\section{Funding}

This study is entirely funded by the Dutch government; no additional grants were received. The government had no role in study design, collection, analysis and interpretation of data and in writing the manuscript.

\section{Availability of data and materials}

The datasets generated and/or analyzed during the current study are not publicly available due to privacy legislation. A fully anonymized dataset of the 676 infants is available from the corresponding author on reasonable request. Depending on the research question, the dataset will be condensed as much as possible.

\section{Ethics approval and consent to participate}

Medical ethical approval was not needed because nobody was subjected to imposed rules or acts [17]. Informed consent of patients was not necessary because the study served public interest, and asking permission was not feasible [16]. The boards of participating hospitals gave permission to extract medical record data.

\section{Consent for publication}

We do not need consent to publish, because the manuscript only contains aggregated data.

\section{Competing interests}

NvdM, ES, AB, AW and HdM have no conflict of interest to declare. FV is an editorial board member for BMC Infectious Diseases.

\section{Author details}

${ }^{1}$ Centre for Infectious Disease Control, National Institute for Public Health and the Environment, PObox 1, 3720BA, Bilthoven, The Netherlands. ${ }^{2}$ Department of Paediatric Immunology and Infectious Diseases, University Medical Hospital Utrecht, Utrecht, the Netherlands. 'University of Groningen, University Medical Centre Groningen/Beatrix Children's Hospital, Groningen, the Netherlands. ${ }^{4}$ Department of Paediatrics, Rijnstate Hospital, Arnhem, the Netherlands.

Received: 4 September 2018 Accepted: 16 October 2019

Published online: 29 October 2019

\section{References}

1. Versteegh FGA, Schellekens JFP, Fleer A, Roord JJ. Pertussis: a concise historical review including diagnosis, incidence, clinical manifestations and the role of treatment and vaccination in management. Rev Med Microbiol. 2005;16(3):79-89. https://doi.org/10.1097/01.revmedmi.0000175933.85861.4e.

2. Van Lier A, Oomen P, Giesbers H, Van Vliet H, Drijfhout I, Zonnenberg-Hoff IF, et al. Immunisation coverage National Immunisation Programme in the Netherlands; year of report 2016. Bilthoven: National Institute for Public Health and the Environment; 2016. Report No.: 2016-0064.

3. van der Maas NAT, Mooi FR, de Greeff SC, Berbers GAM, Conyn-Spaendonck $M A E$, de Melker HE. Pertussis in the Netherlands: is the current vaccination strategy sufficient to reduce disease burden in young infants? Vaccine. 2013;31(41):4541-7. https://doi.org/10.1016/j.vaccine.2013.07.060.

4. Winter K, Zipprich J, Harriman K, Murray EL, Gornbein J, Hammer SJ, et al. Risk factors associated with infant deaths from pertussis: a case-control study. Clin Infect Dis. 2015;61(7):1099-106. https://doi.org/10.1093/cid/civ472.

5. de Greeff SC, de Melker HE, van Gageldonk PG, Schellekens JF, van der Klis FR, Mollema L, et al. Seroprevalence of pertussis in the Netherlands: evidence for increased circulation of Bordetella pertussis. PLoS One. 2010; 5(12):e14183. https://doi.org/10.1371/journal.pone.0014183.

6. de Greeff SC, Mooi FR, Westerhof A, Verbakel JM, Peeters MF, Heuvelman CJ et al. Pertussis disease burden in the household: how to protect young infants. Clin Infect Dis. 2010;50(10):1339-45. https://doi.org/10.1086/652281.

7. Wirsing von Koenig CH, Guiso N. Global burden of pertussis: signs of hope but need for accurate data. Lancet Infect Dis. 2017;17(9):889-90. https://doi. org/10.1016/S1473-3099(17)30357-2.

8. van der Maas NAT, Hoes J, Sanders EAM, de Melker HE. Severe underestimation of pertussis related hospitalizations and deaths in the Netherlands: a capture-recapture analysis. Vaccine. 2017;24(35):4162-6. https://doi.org/10.1016/j.vaccine.2017.06.037.

9. Sobanjo-Ter Meulen A, Duclos P, Mclntyre P, Lewis KD, Van Damme P, O'Brien KL, et al. Assessing the evidence for maternal pertussis immunization: a report from the Bill \& Melinda Gates Foundation Symposium on pertussis infant disease burden in low- and lower-middleincome countries. Clin Infect Dis. 2016;63(suppl 4):S123-S33. https://doi.org/ 10.1093/cid/ciw530.

10. Campbell H, Gupta S, Dolan GP, Kapadia SJ, Kumar Singh A, Andrews N, et al. Review of vaccination in pregnancy to prevent pertussis in early infancy. J Med Microbiol. 2018;67(10):1426-56. https://doi.org/10.1099/jmm.0.000829.

11. Gentile A, Juarez MDV, Lucion MF, Martinez AC, Romanin V, Areso S, et al. Bordetella pertussis (Bp) disease: before (2003-2011) and after (2013-2016) maternal immunization strategy in a pediatric hospital. Vaccine. 2018;36(11): 1375-80. https://doi.org/10.1016/j.vaccine.2018.01.091.

12. Winter $K$, Nickell S, Powell M, Harriman K. Effectiveness of prenatal versus postpartum Tdap vaccination in preventing infant pertussis. Clin Infect Dis. 2016. https://doi.org/10.1093/cid/ciw634.

13. Byrne L, Campbell H, Andrews N, Ribeiro S, Amirthalingam G. Hospitalisation of preterm infants with pertussis in the context of a maternal vaccination programme in England. Arch Dis Child. 2017. https://doi.org/10.1136/ archdischild-2016-311802.

14. Winter K, Nickell S, Powell M, Harriman K. Effectiveness of prenatal versus postpartum tetanus, diphtheria, and Acellular pertussis vaccination in preventing infant pertussis. Clin Infect Dis. 2017;64(1):3-8. https://doi.org/10. 1093/cid/ciw634.

15. Schurink-van 't Klooster TM, De Melker HE. The National Immunisation Programme in the Netherlands; surveillance and developments in 20172018. Bilthoven: National Institute for Public Health and the Environment; 2018. 
16. Wet op de beroepen in de individuele gezondheidszorg den Haag: ministerie van Binnenlandse Zaken en Koninkrijkrelaties; [Available from: http://wetten.overheid.nl/BWBR0006251/2016-08-01.

17. Subjects $\mathrm{CCORHH}$. Your research: is it subject to the WMO or not? The Hague: central committee on research involving human subjects; 2018 [09-07-2019]. Available from: https://english.ccmo.nl/investigators/legal-framework-formedical-scientific-research/your-research-is-it-subject-to-the-wmo-or-not.

18. DutchHospitalData. Gebruikershandleiding Landelijke Basisregistratie Ziekenhuiszorg (LBZ) 2014 Utrecht: Dutch Hospital Data; 2014 [Available from: https://www.dhd.nl/klanten/klantenservice/handleidingen_ formulieren/Documents/Handleiding\%20LBZ.pdf.

19. Farrington CP. Estimation of vaccine effectiveness using the screening method. Int J Epidemiol. 1993;22(4):742-6.

20. Woestenberg PJ, van Lier A, van der Maas NA, Drijfhout $I H$, Oomen PJ, de Melker HE. Delayed start of diphtheria, tetanus, acellular pertussis and inactivated polio vaccination in preterm and low birth weight infants in the Netherlands. Pediatr Infect Dis J. 2014;33(2):190-8. https://doi.org/10.1097/ INF.0000000000000106.

21. van der Leeuw-Harmsen L, Rijninks-van Driel GC, Morshuis RHL, van Lith JMM, Tamminga P. Perinatale Registratie Nederland. Grote lijnen 1999-2012. Utrecht: Stichting Perinatale Registratie Nederland; 2013.

22. Riise OR, Laake I, Vestrheim D, Flem E, Moster D, Riise Bergsaker MA, et al. Risk of pertussis in relation to degree of prematurity in children less than 2 years of age. Pediatr Infect Dis J. 2017;36(5):e151-e6. https://doi.org/10. 1097/INF.0000000000001545

23. Marshall H, Clarke M, Rasiah K, Richmond P, Buttery J, Reynolds G, et al. Predictors of disease severity in children hospitalized for pertussis during an epidemic. Pediatr Infect Dis J. 2015;34(4):339-45. https://doi.org/10.1097/INF. 0000000000000577.

24. Halperin SA, Wang EE, Law B, Mills E, Morris R, Dery P, et al. Epidemiological features of pertussis in hospitalized patients in Canada, 1991-1997: report of the immunization monitoring program--active (IMPACT). Clin Infect Dis. 1999;28(6):1238-43. https://doi.org/10.1086/514792.

25. Zamir CS, Dahan DB, Shoob H. Pertussis in infants under one year old: risk markers and vaccination status--a case-control study. Vaccine. 2015;33(17): 2073-8. https://doi.org/10.1016/j.vaccine.2015.02.050.

26. Langkamp DL, Davis JP. Increased risk of reported pertussis and hospitalization associated with pertussis in low birth weight children. J Pediatr. 1996;128(5 Pt 1):654-9.

27. Elliott E, McIntyre P, Ridley G, Morris A, Massie J, McEniery J, et al. National study of infants hospitalized with pertussis in the acellular vaccine era. Pediatr Infect Dis J. 2004:23(3):246-52.

28. Heininger U, Klich K, Stehr K, Cherry JD. Clinical findings in Bordetella pertussis infections: results of a prospective multicenter surveillance study. Pediatrics. 1997;100(6):E10.

29. Heininger $U$, Weibel $D$, Richard JL. Prospective Nationwide surveillance of hospitalizations due to pertussis in children, 2006-2010. Pediatr Infect Dis J. 2013. https://doi.org/10.1097/01.inf.0000434353.84352.04.

30. WHO. Immunization surveillance, assessment and monitoring: World Health Organization; [Available from: http://www.who.int/immunization/ monitoring surveillance/en/.

31. Crespo Fernandez I, Soldevila N, Carmona G, Sala MR, Godoy P, Dominguez A, et al. Surveillance of hospitalized and outpatient cases of pertussis in Catalonia from 2003 to 2009. Hum Vaccin Immunother. 2013;9(3):667-70.

32. Preziosi MP, Halloran ME. Effects of pertussis vaccination on disease: vaccine efficacy in reducing clinical severity. Clin Infect Dis. 2003;37(6): 772-9. https://doi.org/10.1086/377270.

33. Herzig P, Hartmann C, Fischer D, Weil J, von Kries R, Giani G, et al. Pertussis complications in Germany--3 years of hospital-based surveillance during the introduction of acellular vaccines. Infection. 1998;26(4):227-31.

34. Juretzko P, von Kries R, Hermann M. Wirsing von König CH, Weil J, Giani G. effectiveness of acellular pertussis vaccine assessed by hospital-based active surveillance in Germany. Clin Infect Dis. 2002;35(2):162-7; DOI:CID011391 [pii]. https://doi.org/10.1086/341027.

35. Radke S, Petousis-Harris H, Watson D, Gentles D, Turner N. Age-specific effectiveness following each dose of acellular pertussis vaccine among infants and children in New Zealand. Vaccine. 2017;35(1):177-83. https://doi. org/10.1016/j.vaccine.2016.11.004

36. Hviid A. Effectiveness of two pertussis vaccines in preterm Danish children Vaccine. 2009;27(23):3035-8. https://doi.org/10.1016/j.vaccine.2009.03.041.
37. Malek A, Sager R, Kuhn P, Nicolaides KH, Schneider H. Evolution of maternofetal transport of immunoglobulins during human pregnancy. Am J Reprod Immunol. 1996;36(5):248-55.

38. Schloesser RL, Fischer D, Otto W, Rettwitz-Volk W, Herden P, Zielen S. Safety and immunogenicity of an acellular pertussis vaccine in premature infants. Pediatrics. 1999;103(5):e60

39. Slack MH, Schapira D, Thwaites RJ, Schapira C, Bamber J, Burrage M, et al. Acellular pertussis vaccine given by accelerated schedule: response of preterm infants. Arch Dis Child Fetal Neonatal Ed. 2004;89(1):F57-60.

40. Faldella G, Alessandroni R, Magini GM, Perrone A, Sabatini MR, Vancini A, et al. The preterm infant's antibody response to a combined diphtheria, tetanus, acellular pertussis and hepatitis B vaccine. Vaccine. 1998;16(17):1646-9.

41. Bonhoeffer J, Siegrist CA, Heath PT. Immunisation of premature infants. Arch Dis Child. 2006;91(11):929-35. https://doi.org/10.1136/adc.2005.086306.

42. Nuolivirta K, Koponen $\mathrm{P}$, He Q, Halkosalo A, Korppi M, Vesikari T, et al. Bordetella pertussis infection is common in nonvaccinated infants admitted for bronchiolitis. Pediatr Infect Dis J. 2010;29(11):1013-5.

43. Abu Raya B, Bamberger E, Kassis I, Kugelman A, Srugo I, Miron D. Bordetella pertussis infection attenuates clinical course of acute bronchiolitis. Pediatr Infect Dis J. 2013;32(6):619-21. https://doi.org/10.1097/INF.0b013e3182877973.

44. Korppi M, Hiltunen J. Pertussis is common in nonvaccinated infants hospitalized for respiratory syncytial virus infection. Pediatr Infect Dis J. 2007; 26(4):316-8. https://doi.org/10.1097/01.inf.0000258690.06349.91.

45. Thorburn K, Harigopal S, Reddy V, Taylor N, van Saene HK. High incidence of pulmonary bacterial co-infection in children with severe respiratory syncytial virus (RSV) bronchiolitis. Thorax. 2006;61(7):611-5. https://doi.org/10.1136/thx.2005.048397.

46. Greenberg D, Bamberger E, Ben-Shimol S, Gershtein R, Golan D, Srugo I. Pertussis is under diagnosed in infants hospitalized with lower respiratory tract infection in the pediatric intensive care unit. Med Sci Monit. 2007; 13(11):CR475-80.

47. Cosnes-Lambe C, Raymond J, Chalumeau M, Pons-Catalano C, Moulin F, de Suremain N, et al. Pertussis and respiratory syncytial virus infections. Eur J Pediatr. 2008;167(9):1017-9. https://doi.org/10.1007/s00431-007-0633-6.

48. Goka EA, Vallely PJ, Mutton KJ, Klapper PE. Single and multiple respiratory virus infections and severity of respiratory disease: a systematic review. Paediatr Respir Rev. 2014;15(4):363-70. https://doi.org/10.1016/j.prrv.2013.11.001.

\section{Publisher's Note}

Springer Nature remains neutral with regard to jurisdictional claims in published maps and institutional affiliations.

Ready to submit your research? Choose BMC and benefit from:

- fast, convenient online submission

- thorough peer review by experienced researchers in your field

- rapid publication on acceptance

- support for research data, including large and complex data types

- gold Open Access which fosters wider collaboration and increased citations

- maximum visibility for your research: over $100 \mathrm{M}$ website views per year

At $\mathrm{BMC}$, research is always in progress.

Learn more biomedcentral.com/submission 